\title{
Erratum to: Jane Addams: Progressive Pioneer of Peace, Philosophy, Sociology, Social Work and Public Administration
}

\author{
Patricia M. Shields
}

\section{Erratum to:}

P.M. Shields (ed.), Jane Addams: Progressive Pioneer of Peace, Philosophy, Sociology, Social Work and Public Administration, Pioneers in Arts, Humanities, Science, Engineering, Practice 10, DOI 10.1007/978-3-319-50646-3

In the original version of the book, Patricia M. Shields should be treated as an editor and not as an author in the book metadata on Springer.com. The erratum book has been updated with the change.

The updated original online version for this book can be found at DOI 10.1007/978-3-319-50646-3

\section{P.M. Shields $(\bowtie)$}

Department of Political Science, Texas State University, San Marcos, TX, USA

e-mail: ps07@txstate.edu 